\title{
ADOPTION UNDER ISLAMIC LAW: CORRECTING MISCONCEPTIONS
}

\author{
Abdulraheem Abdulwahid Yusuph*
}

\begin{abstract}
Human dignity depends on caring, on the solidarity between a man and another fellow human being. Among the responsibilities owed by a man towards vulnerable children, particularly orphans and abandoned children, is to protect and preserve their human dignity via adoption. Islamic and Western law have different perspectives and conceptions about adoption. There is a misconception that Islamic law prohibits adoption due to an erroneous conception of verse 23:5 of the Qur'an. This study examines the concept of adoption and the laws regulating it under Islamic law. The study relies on relevant materials, such as Islamic law books, statutes and articles. The study reveals that the case of Zaid ibn Haritha (Prophet Muhammad's adopted son) is the root cause of many misconceptions about adoption in Islam. The study also points out the nuances of the concept of adoption under both Islamic and Western law, showing how Islamic law preserves the integrity of the biological relationship. It concludes that it is not only permissible in Islamic law to adopt a child but preferable as a means of gaining enormous reward in both this life and the Hereafter.
\end{abstract}

Keywords: Adoption, Kafalah, Islamic law, Misconception.

\section{Introduction}

Adoption $^{1}$ is one of the oldest socio-religious institutions, and has been practised in many forms in various societies. ${ }^{2}$ Since ancient times, ${ }^{3}$ adoption has played a central role in ensuring the well-being of children. The institution has been promoted for many reasons, including expanding the social networks of children, strengthening family ties and caring for children deprived of their parents by war, illness, abject poverty or death. ${ }^{4}$ Despite the roles played by adoption in various societies, it assumes an ambiguous responsibility in the social imagination of many religions. ${ }^{5}$ There is a wide range of religious perspectives concerning adoption, from encouragement to limited restriction to total prohibition. ${ }^{6}$

Some Muslims and non-Muslims view adoption under Islamic law as a prohibited act. ${ }^{7}$ This view ignores the sophistication, nuance, and diversity of 
both Western adoption practices under international law and Islamic teachings. ${ }^{8}$ The negative view towards adoption under Islamic law emanates from a misconception concerning the concepts at-tabanni (pre-Islamic adoption) and $k_{\text {afalah }}^{9}$ (Islamic adoption).

As far as adoption is concerned, Islamic law not only allows it but even highly recommends it. For all types of charity, orphans and the poor are mentioned as the prime eligible recipients. Islamic law fully supports the concept of helping orphans and the poor and taking care of them in a family environment. Allah provides a severe punishment for those who infringe the rights of orphans. For example, Allah says: "verily those who unjustly eat up the property of orphans, they eat up only fire into their bellies, and they will be burnt in the blazing Fire!"10 Against this backdrop, this paper seeks to: (i) elucidate some issues relating to the concept of adoption; (ii) contribute to a better understanding of the Islamic legal perspective concerning adoption; (iii) provide some insight into the implications and legal consequences that potentially create a discrepancy between Islamic and Western laws on adoption; and (iv) provide some keystones to help bridge the gap between both laws to achieve the aims and objectives of adoption.

\section{The Historical Background of Adoption in Canon and Jewish Law}

All pre-Islamic divine laws ${ }^{11}$ enjoin taking care of orphans. In Jewish law, individuals who adopt an orphan are highly regarded in society. ${ }^{12}$ Judaism encourages guardianship of orphans as an act of goodness, charity and a respectable social reality. ${ }^{13}$ Although Jewish law provides that the best way for couples to have a child is through reproduction, it makes adoption a possible solution for couples who cannot have children for various reasons. ${ }^{14}$ In the Talmud, ${ }^{15}$ there are several examples of individuals who adopted orphans, for instance Michal, the wife of King David, reared five orphaned children. ${ }^{16}$

Unlike Roman or Western adoption law, Jewish law does not change the legal paternity of the adoptee. ${ }^{17}$ According to Jewish law, the child is tied to his biological parents. ${ }^{18}$ The adoptee may even marry a person from the adopting family. Since the child is not of the adopting family's hereditary blood, the marriage could not be considered incest. ${ }^{19}$ Nevertheless, once a child is adopted, the adoptee must be treated as if he or she were biologically born to the adopter. ${ }^{20}$ If the child is not Jewish upon adoption, he (or she) must go through a full conversion ceremony ${ }^{21}$ before the adoption is complete. Additionally, a child adopted from unknown parents must also go through a conversion process in order to be considered Jewish. ${ }^{22}$ The Talmud explicitly discusses whether or not adopted children raised in the same family environment may marry each 
other, concluding that such marriages are permitted..$^{23}$ One medieval authority, Rabbi Judah of Regensburg, however, decreed that such marriages should not be performed. ${ }^{24}$ This decree has not generally been accepted. ${ }^{25}$ Although legally permitted, few such marriages are performed.

In Israel, adoption has been recognised as a legal institution since 1960. Before that period, there were no general procedures regulating adoption. Adoption in Israel is currently governed by the 1981 Adoption of Children Law. According to that law, adoption creates ties between the adoptive parent and adopted child equivalent to natural filiations. ${ }^{26}$ It is significant to realise that the institution of adoption in Jewish law is different from adoption in Western law. In Jewish law, adoption functions as an agency theory and focuses entirely on natural relationships to establish parental rights and duties.

The Catholic Church sees adoption as a natural remedy for infertility and highly preferable to the use of reproductive biotechnologies. The adoption of children whose parents are unable to care for them is also considered part of the mission of a Christian family. ${ }^{27}$ The Catholic Church plays a significant role in preserving the institution of adoption as outlined in Roman law, which it made its own with all its legal consequences. ${ }^{28}$

Pope Nicholas I (858-867) spoke of this law as revered when inculcating its observance upon the Bulgarians. Hence, adoption under the title cognatio legalis (legal relationship) was recognised by the Catholic Church as a diriment impediment to marriage..$^{29}$ This legal relationship originated from its similarity to the natural relationship and resulted in: ${ }^{30}$

- Civil paternity between the adopter and the adopted, even after the dissolution of the adoption;

- Civil brotherhood between the adopted and the legitimate natural children of the adopter until the adoption is dissolved or the natural children are placed under their control (sui juris);

- Affinity arises from the tie of adoption between the adopted and the adopter's wife, and between the adopter and the adopted's wife. This affinity is not removed by the dissolution of the adoption.

This ostensibly reveals that the Western law of adoption emanates from canon law.

\section{Adoption in Islamic Law}

Adoption was a custom that was recognised and practised in pre-Islamic Arab societies. ${ }^{31}$ During this era, an adopted child legally became as one who had been born to the adoptive parents. Consequently, the rules of inheritance, affinity ${ }^{32}$ and 
consanguinity ${ }^{33}$ were all applicable, rendering marriage between an adopted child and any member of the adoptive family impossible. ${ }^{34}$ In classical Islamic law, this practice is termed at-Tabanni. ${ }^{35}$

The Prophet Mohammed adopted a freed slave by the name of Zayd bin Harith before the advent of Islam. Zayd reportedly chose to stay with the Prophet rather than return to his father, who had come to claim him after he was freed. The Prophet's proposal to "adopt" (tabanna) Zayd was accepted by him. As it was the Arab custom of the pre-Islamic era, the Prophet Muhammad declared that he had adopted Zayd to his fellow tribesmen, and said: "O people of Quraish, be a witness that he is my son, he inherits me, and I inherit him." ${ }^{36}$ The matter continued as part of the tabbani practice until the revelation of verses 33:4-5 of the Qur'an:

Allah has not made for any man two hearts inside his body. Neither has He made your wives whom you declare to be like your mothers your real mothers (az-zihar). Nor has He made your adopted sons your real sons. That is but your saying with your mouths. However, Allah says the truth, and He guides to the (Right) Way. Call them (adopted sons) by (the names of) their fathers: that is more just with Allah. However, if you know not their father's (names call them) your brothers in faith and mawalikum (your freed slaves). Moreover, there is no sin on you concerning that in which you made a mistake, except regarding what your hearts deliberately intend. Moreover, Allah is Ever Oft-Forgiving, Most Merciful. ${ }^{37}$

Before the revelation of this verse, Zayd was known as Zayd, the son of Muhammad, instead of Zayd, the son of Harith. ${ }^{38}$ Moreover, Zayd married Zaynab bint Jahsh, the Prophet's cousin, before then divorcing her. ${ }^{39}$ Subsequently, the Prophet married her. In the pre-Islamic era, it was taboo for a man to marry the divorced wife of his adopted son due to the relationship of descent created by adoption. An uproar thus arose among the people concerning the marriage between the Prophet and Zaynab. To defend the Prophet and clarify Islamic law on issues relating to adoption (tabanni), Allah said:

And (remember) when you said to him (Zayd bin Harith) on whom Allah has bestowed Grace (by guiding him to Islam) and you (O Muhammad too) have done a favour (by manumitting him): 'Keep your wife to yourself and fear Allah'. However, you did hide in yourself (i.e. what Allah has already made known to you that He will give her to you in marriage) that which Allah will make manifest, you did fear people (i.e. their saying that Muhammad married the divorced wife of his 
manumitted slave) whereas Allah had a better right that you should fear him. So when Zayd had accomplished his desire from her (i.e. divorced her), we gave her to you in marriage, so that (in future) there may be no difficulty to the believers in respect of (the marriage of) the wives of their adopted sons when the latter have no desire to keep them. Moreover, Allah's Command must be fulfilled. ${ }^{40}$

Upon the revelation of these verses, Zayd's adoption (at-tabani) was rescinded and his name returned to his former name (Zayd bin Harith). This incident and the legal rules derived from the above verses subsequently made it lawful for a man to marry the divorced wife of his adopted son, contrary to the prevailing custom in Arabia. ${ }^{41}$ Islamic Jurists also relied on these verses to negate the creation of any fictive lineage..$^{42}$ Moreover, scholars have also used the verses to postulate that consanguinity is not deemed or achieved through adoption. Based on this, classical Islamic jurists have unanimously held that the pre-Islamic practice of al-tabanni is prohibited. ${ }^{43}$ This prohibition is the reason why some classical Islamic law books do not discuss extensively the topic of at-tabanni. Islamic law scholars, however, believe that all Muslims have a communal obligation to ensure that homeless and parentless children have a guardian and family to care for them. ${ }^{44}$ Therefore, the concept of Kafala (Islamic adoption) was developed as an alternative system providing orphans with a family environment and the financial protection of a guardian, without the risk of obliterating lineage (nasab). ${ }^{45}$

\section{Adherences and Legal Implication of Adoption: Islamic and Western Perspectives}

In the Western system, adoption not only means that a child is given into the care of another person; it also means that the adopted child will bear the family name of the adoptive parent. For example, if Mr Kerry Cameroon adopts a child named Michael Bush-Clinton, he will become Michael B. Cameroon. If this adoption took place in infancy, then most probably the child will never come to know his real family name. Islam does not accept this adoption practice. In pre-Islamic Arabia, the adoption system was similar to what we now see in the West, with the child taking the family name of the adoptive father. When Islam came, it categorically rejected this practice. ${ }^{46}$ Nevertheless, both Western and Islamic perspectives are concerned with the welfare of the child, especially an orphan, despite any legal divergences between them. Here are the main differences and their legal implications in Islamic law: 
Lineage and Naming: The Western form of adoption is similar to al-tabanni, which involves making another's child one's own and treating the child in the same way one would treat a biological child regarding family relationship, guardianship, maintenance, inheritance, lineage and so on. ${ }^{47}$ Indeed, an essential characteristic of Western adoptions is that the adopted child is no longer related to his biological parents. ${ }^{48}$ Legally, the adoptive parents become the biological parents, creating a legal fiction regarding the relationship between the adopted child and the adoptive parents. ${ }^{49}$ In Islamic law, on the other hand, the creation of fictive kinships is strictly forbidden (haram) as it breaks filial continuity. Allah says: “...nor has He made your adopted sons your real sons....call them (adopted sons) by (the names of) their fathers: that is more just with Allah. However, if you know not their fathers' (names, call them) your brothers in faith and Mawalikun (your freed slaves)." ${ }^{50}$

This verse has generally been misinterpreted as a ban on adoption. However, classical Islamic scholars held that there was prohibition and harm in dissimulation, not in adoption. According to most classical and traditional Islamic scholars, adopted children cannot be considered as related either by name or otherwise to the bloodline of the adoptive family. This position contradicts the prevalent Western approach to adoption..$^{51}$ The Quranic injunction against lying to the adopted child is entirely in tandem with modern psychiatric thought. The American Academy of Pediatric Psychiatry strongly recommends for psychological reasons that adopted children be informed that they are adopted. ${ }^{52}$ This principle is also embedded in international laws. According to Articles 7 and 8 of the United Nations Convention on the Rights of the Child (1989), each child has the right to know and to preserve his or her identity. ${ }^{53}$

In situations where the lineage of an adopted child is unknown, Islam the surname of the adoptive family should not be attributed to the child. However, many Muslim-majority countries allow for the transference of the family name of the guardian to the child if the child is of unknown heritage. According to article 92 of the Child Law No 12 (1996) in Egypt, for example, "an orphan or a child of unknown parentage, male or female, carries the surname of the guardian family to be attached at the end of his/her first name. This action should be documented in the child's file, and it does not lead to any effects related to adoption." ${ }^{54}$

Consanguinity and Marriage Prohibition: In the Western context, adopted children are prohibited from marrying their adoptive parents' biological children ${ }^{55}$ and, of course, the parents themselves in the event of their divorce or the death of a spouse. This prohibition is extended throughout the circle of biological relationship. ${ }^{56}$ According to the Qur'an, however, the relatives one is forbidden to marry include: 
your mothers, your daughters, your sisters, your father's sisters, your mother's sisters, your brother's daughters, your sister's daughters, your foster mothers who gave you suck, your foster milk suckling sisters, your wives' mothers, your step-daughters under your guardianship, born of your wives to whom you have gone in, but there is no sin on you if you have not gone in them (to marry their daughters), the wives of your sons who (spring) from your own loins, and two sisters in wedlock at the same time, except for what has already passed; verily, Allah is Oft-Forgiving, Most Merciful. ${ }^{57}$

In Islamic law, those who are prohibited from marrying are known as unmarriageable kin. The status of unmarriageable kin occurs by one of three means: marriage, kinship, or milk-foster relationship (having breastfed).

In Islamic law, an adopted child, unless breastfed by the adoptive mother, ${ }^{58}$ is considered marriageable (non-mahram) by the adopted family. Therefore, marriage between a child raised through kafalah and the biological children of the adoptive family is legal under Islamic law. In contrast, most Western states consider marriage between adopted siblings incestuous and prohibited, few countries in the West permitting an adopted child to marry within the adoptive family. ${ }^{59}$

Inheritance: Although severing an adopted child's ties with their biological parents, substituting them with fictive ties to adoptive parents, Western adoption nevertheless allows an adopted child to inherit wealth from his biological parents. ${ }^{60}$ However, while an adopted child maintains his right to inherit from his biological parents, he is not allowed the same right of inheritance from his adoptive parents. ${ }^{61}$ In Islamic law, an adopted child's properties are also separated from an adoptive parent's properties, ${ }^{62}$ the latter being forbidden from mixing their assets with those of the former. ${ }^{63}$ This was of significance in the pre-Islamic al-tabbani context because, in some cases, adoption took place to usurp the wealth of orphans. ${ }^{64} \mathrm{But}$, since there is no verse in the Qur'an or text from the Sunnah that impedes an adoptive parent from giving or bequeathing properties to an adopted child, Islamic jurisprudence provides that the adopted child can be given inheritance shares in the form of wasiyyah to the tune of one-third or less of the adoptive parent's wealth before their death. ${ }^{65}$ Adoptive parents can also set up an endowment (waqf) with the intent of sustaining and caring for an adopted child after their demise. ${ }^{66}$ 


\section{Acknowledgement of Islamic Adoption (Kafalah) in International Law}

The United Nations Convention on the Rights of the Child (CRC), the African Charter on the Rights and Welfare of the Child (African Children's Charter), the 1993 Hague Convention on Protection of Children and Co-operation in Respect of Inter-country Adoption (Hague Adoption Convention) and the 2009 United Nations Guidelines for the Alternative Care of Children (UN Guidelines), ${ }^{67}$ stress the need for children to be brought up in a family environment. The need for a child to be brought up in a family environment is of paramount importance for the development of a child's personality, to be a good citizen in society ${ }^{68}$ Because of this, CRC, the African Children's Charter, and the UN Guidelines, give an additional level of support and protection to children who are deprived of their natural family environment. ${ }^{69}$

Islamic law also emphasises caring for less privileged children by various means, especially through kafalah (Islamic adoption) ${ }^{70}$ Islamic adoption as a subject of international law was first mentioned in the 1986 UN Declaration on Social and Legal Principles Relating to the Protection and Welfare of Children, with Special Reference to Foster Placement and Adoption Nationally and Internationally (henceforth 1986 Declaration). The 1986 Declaration presented the first internationally agreed-upon standards of care for children whose parents are 'unavailable' or 'inappropriate'. ${ }^{71}$ Islamic adoption is also recognised in the 1996 Hague Convention on Jurisdiction, Applicable Law, Recognition, Enforcement, and Co-operation in Respect of Parental Responsibility and Measures for the Protection of Children. ${ }^{72}$

Kafalah is a mechanism to ensure the "protection of the person or property of [a] child." "73 In the UN Guidelines, kafalah is recognised as an "appropriate and permanent solution" for children who cannot be kept in or returned to their original families. In effect, kafalah can be regarded as an internationally recognised form of alternative care for children deprived of their natural family environment, as well as a measure for providing "a global system for improving the protection of children in international situations." ${ }^{\prime 4}$

During the drafting process of CRC, the inclusion of adoption as a form of alternative care generated debate among delegates from Islamic states due to the prohibition of Western conceptions of adoption under Islamic law. The first objection was raised by the permanent representative of Bangladesh, who stated that such adoption would result in complex problems relating to inheritance rights in Islamic jurisdictions. ${ }^{75}$

Therefore, the recognition of Islamic adoption ( $k$ afalah) as an alternative care option in the CRC was a compromise, to accommodate the religious, social, and 
cultural differences of the various states party to the agreement. Article 21 of CRC was initially drafted to read that "state parties...shall undertake measures, where appropriate, to facilitate the process of adoption of the child." implication of this was that states must put in place mechanisms for adoption. This positive obligation imposed on the state, however, was hardly acceptable to Islamic countries because it meant those states were obliged to provide for adoption. Eventually, a compromise was reached to the effect that states were not obliged to recognise or set up a system of adoption. Article 21 of CRC then read: "State Parties that recognise and/or permit the system of adoption shall ensure that the best interests of the child shall be the paramount consideration." ${ }^{.77}$ This approach was considered more realistic as it accommodated the various concerns raised, in addition to the fact that adoption is not the only solution for children requiring alternative care. ${ }^{78}$

The recognition of Islamic adoption (kafalah) in the text of CRC was momentous because it reflected the role of cultural, social and religious factors in the drafting of international instruments and the place of compromise in resolving differences among state parties. However, despite this compromise, some Muslim states, such as Egypt and Jordan, although ratifying CRC, continued to have reservations about the adoption provisions. ${ }^{79}$ The CRC Committee expressed concerns over such reservations, since the text of Article 21 should have made them unnecessary; the introductory part of Article 21 already makes it clear that the provisions on adoption do not apply to these countries. ${ }^{80}$

There have been many other recent developments on the inclusion of Islamic adoption (kafalah) in international law. In 2002, Italy ratified the Hague Adoption Convention but, since kafalah was not within the scope of that convention, it did not immediately acknowledge Islamic adoption for the purpose of allowing Muslim children adopted from Morocco or elsewhere to be united with their caregivers in Italy. ${ }^{81}$ This position changed in 2005 by a decree of the Constitutional Court of Italy (decree 347, issued 29 July 2005). Based on that, the peculiarities of kafalah are now recognised in Italy. ${ }^{82}$ Also, in 2007 an outreach programme was launched in New South Wales, Australia, specifically targeting Muslims and seeking to reinforce awareness that the country's adoptions are open and allow children to retain their lineage legally. This initiative, the first of its kind in a Western nation, sets a good example for other jurisdictions. ${ }^{83}$ Also, the European Court of Human Rights (ECHR), in Harroudj v. France, 4 October 2012, ${ }^{84}$ also moved to recognise Islamic adoption in international law. 


\section{Conclusion}

The concept of adoption is recognised by all religions, especially Islam. There are many verses in the Qur'an which encourage humanity to care for the less privileged, including orphans. Allah says:

Worship Allah and join no one with Him (in worship); and do good to parents, kinsfolk, orphans, al-Masakin (the needy), the neighbour who is near of kin, the neighbour who is [a] stranger, the companion by your side, the wayfarer (you meet), and those (slaves) whom your right hands possess. Verily, Allah does not like such as are proud and boastful. ${ }^{85}$

It is evident that this verse highlights the need to take care of orphans and other needy children. The prophetic traditions complement the Qur'an in this regard, the Prophet saying "The one who looks after an orphan and I will be like these two (referring to his fingers) in Paradise. ${ }^{186}$ Under Islamic law, it is a great sin to abandon a child, whereas taking custody of an underprivileged child is a great act of worship. Therefore, it is a misconception amongst some Muslims and non-Muslims that Islamic law prohibits adoption. This paper has analysed the concept of adoption under Islamic and Western law, revealing that the former differs from the latter on the consequential implication of adoption in inheritance, consanguinity, lineage, and marriage prohibition.

\section{Actionable Policy Recommendations}

This paper concludes by recommending the following:

- Adopted children cannot have the same rights as biological children, especially with regards to the distribution of an estate.

- Muslim scholars need to continuously enlighten the public about the social significance of adoption, and thereby contribute immensely towards the development of the institution.

\section{Notes}

* AbdulRaheem Abdul Wahid Yusuph, Department of Islamic Law, Faculty of Law, al-Hikmah University, Ilorin. Email: ayabdulraheem@alhikmah.edu.ng. 
1. Many definitions of adoption exist, with different conceptions creating the different legal rules observed in Western and Islamic law. According to Ashley Daw Harvel, in his book The Myth of the Unknown Child Creating a New Face for Adoption in America, "Adoption is the legal creation of a parent-child relationship, with all the responsibilities and privileges thereof, between the child and adults who are not his or her biological parents, with the concomitant permanent severing of all connections and relationships with the biological parents." This definition is not compatible with the principles of Islamic law; severing the biological ties of an adopted child is expressly forbidden in Islam. In the book The Adoption Triangle: The Effects of the Sealed Record on Adoptees, Birth Parents, and Adoptive Parent, however, it is stated that "adoption is the legal creation of a family relationship analogous to that of parents and child between a child and adults who are not the biological parents while not severing or negating the child's biological connection." This definition is in tandem with Islamic law. Also, in an article entitled 'Classical Religious Perspective on Adoption Law,' adoption is defined as "Arranging for the care of children in homes with adults who are not their biological parents." This appears to be closest to the pre-modern or classical Islamic perspective.

2. United Nations, Child Adoption: Trends and Policies (New York: United Nations, 2009), 5.

3. Ibid., 25 .

4. Ibid.

5. Faisal Kutty, Islamic Law and Adoption Disciplines (London: Cambridge Scholars Publishing, 2014).

6. Ibid.

7. That is why some writers claim adoption is prohibited. For example, Taslim Nasreen said that "There are 2.1 billion Muslims in the world. But the sad news is, not a single Muslim is allowed to adopt a poor homeless child because 'the religion of peace' forbids abortion." For more detail, see Taslim Nasreen, 'Islam's Most Terrible Law: It prevents Muslims from Adopting Children.’ Available at: http://freethoughtblogs.com/taslima/2012/08/13/islams-most-terrible-law-itprohibits-adoption-of-children/. (Accessed on: 15 August 2016). Also, research conducted by Yusra Gomma, where Muslims from Michigan, Washington, Indiana and Wisconsin were interviewed about adoption, revealed a common perception that Islam prohibits adoption. For more detail, see Yusra Gomma, 'The Case for Adoption in Islam.' Available at http://www.patheos.com/blogs/ altmuslim/2013/05/the-case-for-adoption-in-islam/. (Accessed on: 19 October 2016).

8. Kutty, Islamic Law, 5.

9. The Islamic institution of kafala is a form of foster care for children. It is often defined as a commitment to undertake the maintenance of a child, including education, in the same way a parent would for their biological child. Even though kafala arrangements are always intended to be permanent (in the sense that they last until the child reaches adulthood), they do not create a legal parent-child status (legitimate filiation) producing specific personal status legal entitlements. For more detail, see Mosa Sayed, 'The Kafalah of Islamic Law: How to Approach in the West.' Available at: www.diva-portal.org/smash/record.jsf?pid= 
diva2\%3A6 84707\&dswid=-474http://www.divaportal.org/smash/record.jsf?pi $\mathrm{d}=$ diva2\%3A684707\&dswid=-474. (Accessed on: 13 August 2016).

10. Q. 4:10.

11. Divine law is defined here as any law that comes directly from God, as in contrast to man-made law. Unlike man-made law, which is independent on human beings, divine law is eternal and constant, not subject to change. Divine laws are contained in sacred religious texts, such as the Torah, the Holy Bible, and Qur'an. For more detail, see <http://www.newadvent.org/cathen/09071a. htm. (Accessed on: 12 October 2016).

12. Pollack Daniel, Moshe Bleich, Charles J. Reid, and Muhammad Fadel, 'Classical Religious Perspective of Adoption Law,' Notre Dame Law Review 79, no. 2 (2004): 5 .

13. Ibid., 47.

14. Eseinberg Ronald 'Issues in Jewish Ethics: Adoption', Available at http://www. jewishvirtuallibrary.org/jsource/Judaism/adoption.html. (Accessed on: 18 September 2016).

15. The Talmud is a huge collection of doctrine and legal opinions compiled before the $8^{\text {th }}$ century CE by Jewish teachers. The Talmud, which often cites the Old Testament, is the basic book of Jewish law. For more detail, see http://www. come-and-hear.com/editor/whatis.html. (Accessed on: 12 October 2016).

16. United Nations, Child Adoption, 47.

17. Michael J. Broyde, 'Adoption and Establishing Parental Status: Jewish Law.' Available at: http://www.jlaw.com/Articles/maternity4.html. (Accessed on: 13 October 2016).

18. Ronald, 'Issues in Jewish Ethics,' 5.

19. Ibid.

20. Ibid.

21. Orthodox Jewish law requires that the potential convert must undergo kabbalat ol mitzvot (agreement to follow the commandments), mila (circumcision) and tevilah (immersion in a mikvah, or ritual bath). The whole procedure must be supervised by a Beit Din (court) of three people. Note that the members of the Bet Din must be acceptable witnesses. According to Orthodox Jewish law, a witness must scrupulously observe all the laws, particularly Shabbat. From an Orthodox standpoint, therefore, any Jew who does not follow Orthodox standards of practice - rabbi or not - would not be qualified to sit on a Beit Din. For more detail, see 'Issues in Jewish Ethics: Conversion to Judaism.' Available at: http:// www.jewishvirtuallibrary.org/jsource/Judaism/Conversion.html. (Accessed on: 19 October 2016).

22. Ibid.

23. Babylonian Talmud 3, Satab 43b.

24. Ibid.

25. Broyde, 'Adoption and Establishing Parental Status,' 3.

26. United Nation, 'Convention on the rights of the child,' Periodic Reports of States Parties. Available at: www2.ohchr.org/english/bodies/crc/docs/co/CRC-C-ISRCO-2-4.pdf. (Accessed on: 24 October 2016).

27. Ibid., 44.

28. Richard Burtsell, 'Canonical Adoption,' New Advent. Available at: http://www. newadvent.org/cathen/ 01147b.htm. (Accessed on: 28 October 2016). 
29. Ibid.

30. Ibid

31. Usang Assim and Julia Sloth-Nielsen, 'Islamic Kafalah as an Alternative Care Option for Children Deprived of a Family Environment,' African Human Rights Law Journal 14, no. 2 (2014): 21-8. Also see Sayed, 'The Kafala of Islamic Law,' 22.

32. Affinity means a relationship a person has to the blood relatives of a spouse by virtue of marriage. The doctrine of affinity developed from a maxim of Canon Law that a husband and wife were made one by their marriage. There are three types of affinity: direct (between the husband and his wife's relations by blood or between the wife and her husband's relations by blood), secondary (between a spouse and the other spouse's relatives by marriage) and collateral (between a spouse and the relatives of the other spouse's relatives). The determination of affinity is important in various legal matters, such as deciding whether to prosecute a person for incest or whether to disqualify a juror for bias.

33. Consanguinity is the degree of relationship between family members who share at least one common ancestor. It is the blood-relationship (cognatio naturalis), or the natural bond, between persons descended from the same stock. When persons are related by a direct line of descendancy from a common ancestor, it is called lineal consanguinity. When persons are related by descendancy from a common ancestor, but not in a direct line, it is called collateral consanguinity.

34. Kutty, Islamic Law, 15.

35. Al-Tabbani is defined as an act whereby one person takes another as a son. This practice entails that the biological child of one person is made the child of the adoptive parent(s), with the child standing on the same footing as the adoptive parent's other children (if any) in terms of family relationship, rights to custody, guardianship, support, inheritance, lineage, consanguinity. This practice is the legal conception of adoption as understood and practiced in the Western world. For more detail, see Ella Landau-Tasseron, 'Adoption, Acknowledgement of Paternity and False Genealogical Claims in Arabian and Islamic Societies,' Bulletin of the School of Oriental and African Studies 66, no. 2 (2003): 169.

36. Al-Sabuny Muhammad, Tafseer Ayatul-Ahkam minal-Qur'an (Damascus: Maktabatul-Gazal, 1981), 249.

37. Q. 33:4-5.

38. In Islamic law, fatherhood derives from legitimate sexual intercourse. A man does not become the 'father' of a child unless the child was the product of lawful intercourse. Therefore, it is prohibited for the biological father to married his son's divorced wife. For more detail, see Q. 4:23

39. For more enlightening facts about the marriage of Zaynab bint Jash, see Ehteshaam Gulam, 'Fictional Stories about Prophet Muhammad: Zaid, Zanyab Bint Jash and Prophet Muhammad.' Available at: http://www.answeringchristian-claims.com/Zaid_Zanyab_ProphetMuhammad.html>. (Accessed on: 21 October 2015).

40. Q. 33:37.

41. Muhammad Ali Sabuny, Safwatul-Tafsir (Egypt: Darul Sabun, 1995), 470.

42. Ibid., 4-5.

43. Some Orientalists, including Tasleem Nasreen, claim the Prophet abolished attabbani in order to fulfil his desire to marry his son Zayd's wife. This position is 
refuted, however, by a holistic reading of Q. 33:37, which shows that the Prophet was against the divorce. In fact, according to a tradition narrated by Aisha, the Prophet hesitated before marrying Zaynab for fear of what people might think. The verse makes it clear that God ordered him to marry her, cautioning him to fear God and not the people. For more detail, see Gulam, 'Fictional Stories about Prophet Muhammad,' 43.

44. America Society for Muslim Advancement, 'Adoption and the Care of Orphan Children: Islam the Best Interest of the Child.' Available at http:// www.wisemuslimwomen.org/about/shuracouncil/. (Accessed on: 25 October 2016).

45. Zuhaily Wahbah, Alwajiz fi Fiqh Islami (Damascus: Dar-Fikr, 2006), 199.

46. Sayid Muhammad Rizvu, 'Adoption in Islam.' Available at: https://www.alislam.org/articles/adoption-islam-sayyid-muhammad-rizvi. (Accessed on: 15 October 2016).

47. Kutty, Islamic Law, 36.

48. Ibid.

49. Ibid.

50. Q. 33:4-5.

51. Kutty, Islamic Law, 34.

52. W. H. Borham, 'The Adopted Child,' Hood's Magazine 10, no. 2 (1958): 145146.

53. The United Nations, Convention on the Rights of the Child. Available at: http:// www2.ohchr.org/english/law/crc.htm. (Accessed on: 9 October 2016).

54. Ibid.

55. For example, in the United States of America, an adopted brother and sister who were not related to each other by blood were refused a marriage license because state law included adoptive relations within the ban on consanguineous marriages. The Colorado Supreme Court held that the prohibition violated the adopted siblings' rights to equal protection because of the absence of physical detriment to any offspring. Nor does the statute further the state interest in family harmony, since family harmony in this case would be served by allowing the marriage, which was approved by the adoptive parents and their church. See Israel v. Allen Supreme Court of Colorado, 577 P.2d 762 (1978) No.2783. Available at: http://law.justia.com/cases/colorado/supreme-court/1978/27823. html. (Accessed on: 13 November 2016).

56. E. I. Nwogugu, Family Law in Nigeria (Nigeria: HEBN Publishers Plc, 1990), 322. Also see United Nations, Child Adoption: Trends and Policies (New York: Department of Economic and Social Affairs, 2009), 67.

57. Q. 4:23.

58. If a child is two years old or younger and breast-fed directly by their adoptive mother for at least a day and a night (or fifteen times consequently), he/she will become mahram to the new family and cannot marry from within it.

59. Kutty, Islamic Law, 59.

60. Nwogugu, Family Law in Nigeria, 321. For example, the Kwara State Adoption Law provides that: "For the purpose of devolution of property on the intestacy of an adopter, an adopted child shall be treated as the lawful child of the adopter and not as the child of any other person." For more detail, see S15 Kwara 
State Adoption Law 1987, No 4 of 2000. See also S13 Lagos State Adoption Law S14(2), S10(3) and United Nation, Child Adoption: Trends and Policies, 67.

61. Ibid.

62. The adoptive parent cannot inherit the property of their adopted child.

63. Ahmad H. Sakr, 'Adoption and Fostering: The Islamic Viewpoint,' The Muslim World League Journal 31, no 2: (2016): 25-35.

64. Ibid. In the Qur'an, Allah forbids adoptive parents from usurping or recklessly spending the property of their adopted children or orphans: "And give the orphans their property. And take not in exchange the bad of yours for what is good of theirs. And consume not their property with your own property. Truly this has been criminal, a hateful sin" (4:2). In another verse, Allah says: "Truly those who consume the wealth of orphans with injustice, consume only fire into their bellies" (4:10).

65. Kutty, Islamic Law, 68.

66. Ibid., 75.

67. UN General Assembly, A/RES/64/142, 2010. Available at: https://www.unicef. org/protection/ alternative_care_Guidelines-English.pdf. (Accessed on: 10 October 2016).

68. Para 4, Preamble to the African Children's Charter; para 6, Preamble to CRC; para 1, Preamble to The Hague Adoption Convention. United Nation Human Rights Office of the High Commission 'Optional Protocol to the Convention on the Rights of the Child.' Available at: http://www.ohchr.org/EN/ProfessionalInterest /Pages/OPSCCRC.aspx. (Accessed on: 12 October 2016).

69. Art 20 CRC; art 25 African Children's Charter in African Union, 'The African Charter on the Rights and Welfare of the Child (ACRWC)'. Available at: http:// pages.au.int/acerwc/documents/african-charter-rights-and-welfare-child-acrwc. (Accessed on: 15 November 2016).

70. Kutty, Islamic Law, 89-99.

71. Usang M. Assim, 'In the Best Interest of Children Deprived of a Family Environment: A Focus on Islamic Kafalah as An Alternative Care Option,' Unpublished LL.M Thesis, University of Pretoria (2009), 51.

72. Assim and Julia, 'Islamic Kafalah as an Alternative Care Option,' 325.

73. Ibid., 321.

74. Ibid., 308.

75. In reference to international human rights, most Muslim states have ratified the UN Convention on the Rights of the Child (CRC). Nevertheless, many Muslim states who ratified the CRC expressed reservations concerning its potential conflict with Islamic law. A number of Muslim states, including Egypt, Jordan, Kuwait, Maldives, Oman, Syria, and the United Arab Emirates pointed to the provisions relating to adoption as the reason behind their reservations. For more detail, see A. D. Gonzalez, 'The Hague International Adoption Act and its Interaction with Islamic law: Can an Imperfect Enforcement Mechanism Create Cause for Concern?' Gonz. J. Int'l L. 10, no. 2 (2007): 438.

76. Ibid., 431.

77. Ibid., 420.

78. Assim and Julia, 'Islamic Kafalah as an Alternative Care Option,' 319. 
79. Ibid, 320.

80. Child Rights International Network (CRIN), Article 21 of CRC. Available at: https:/www.crin.org/en/home/ rights/convention/articles/article-21-adoption. (Accessed on: 29 October 2016).

81. Assim and Julia, 'Islamic Kafalah as an Alternative Care Option,' 309.

82. Ibid., 305.

83. Ibid., 311.

84. Harroudj v. France, case no 43631/09 of 04/10/2012. The ECHR upheld France's refusal to allow an Algerian woman to adopt an Algerian baby already under her care and control pursuant to the Islamic kafalah guardianship system. The Harroudj decision focused and turned on other issues, but for our purposes the Chamber's observations on the kafalah system are timely and encouraging. The court observed that under the UN Convention on the Rights of the Child, the kafalah model is accepted and defined as 'alternative care,' which it deemed on par with adoption. The court also noted that the fact kafalah is acknowledged under international law should be a decisive factor in determining how states accommodate it in their domestic law and deal with any conflicts that may arise. The court further noted that kafalah was fully accepted in French law and the granting of guardianship to Harroudj enabled her to make all the decisions in the child's interest. In other words, Harroudj was not deprived of any rights by not being allowed to change the kafalah to adoption. This acknowledgement is a great step in the right direction and provides much in working toward a mutually accommodating framework for Islamic adoptions.

85. Q. 4:36, 2-10.

86. Muhammad Muhsin Khan, Sahih Bukhari (Bangalore: Peace Vision, 1979), 122. 